Canadian Journal of Family and Youth, 7(1), 2015, pp 87-113

ISSN 1718-9748 ( ) University of Alberta

http://ejournals.library.ualberta.ca/index/php/cjfy

\title{
Test of Work-to-Family and Family-to-Work Models of Conflict and Satisfaction: An Analysis of Dual Career Couples in Bangladesh
}

\author{
Rahman, T., Tabassum, A. and Jahan, K.
}

\begin{abstract}
Greater access of women to education and the job market has led to the increased participation of women in professional employment throughout the world. Bangladesh is no exception from this trend of change which is creating the phenomenon of dual-career couples (two working people in a committed relationship). This trend has radically changed traditional family structures and gender roles in society. These types of couples need to integrate both their work and family life together. This is creating challenges for both dual-career couples and their employers. Past research has posited that the imbalance between work and family lives, or the conflict between work and family lives of the dual-career couples can significantly reduce employee productivity, performance, job satisfaction, family satisfaction, and life satisfaction. This, in turn, hinders the performance of a business by affecting its organizational innovation, efficiency, and effectiveness.

The current study tested predictions regarding the nature of relationships among these variables on 180 dual career couples $(\mathrm{N}=360)$ in Bangladesh. Literature reviews suggested two forms of conflict; work-to-family conflict and family-to-work conflict among these dual career couples. Models were developed by addressing these two types of conflict and testing the relationship with various types of satisfaction. A structured questionnaire was used as the primary source for data collection. Results reveal that work-to-family conflict negatively predicts job satisfaction and life satisfaction. No evidence is found regarding the relationship of family-towork conflict with job and family satisfaction.
\end{abstract}

Tasnuva Rahman is currently working as an Assistant Professor at the Faculty of Business Administration of Eastern University. She had her BBA and MBA from University of Dhaka. She has several publications in the international journals. Her research interests are work-family conflict, quality of work life, service quality, etc.

Ayesha Tabassum is currently working as an Assistant Professor at the Faculty of Business Administration of Eastern University. She had MBA from North South University. She has several publications in the international journals. Her research interests are quality of work life, workahlolism, work-family conflict, service quality, banking sector, etc.

Kursia Jahan is currently working as an Assistant Professor at the Faculty of Business Administration of Eastern University. She had graduated from University of Dhaka in Statistics. Her research interests are workfamily conflict, quality of work life, service quality, etc. 
Rahman, Tabassum, and Jahan

\section{Introduction}

Societal changes over the past few decades include a dramatic increase in the numbers of women in the workplace of Bangladesh. In the present situation of urban Dhaka, the capital city of Bangladesh, a single income is no longer sufficient to maintain the family (Khan, 2004). This is why female participation in the workforce has increased significantly in all employment sectors of Bangladesh. With the increase in dual-income families, conflict between work and family has reached a crisis (Beauregard, 2006). Work-to-family conflict (WFC), that is, the interference between work and family life is now a common event (van Daalen, Willemsen \& Sanders, 2006). As a result, the integration of work and family has become an important concern for dual career couples and as well as for their employers in the changing global business environment because the causes and consequences of interaction between these two domains are crucial for both employees and their employers (Frone, 2003).

Rapoport and Rapoport (1969) coined the terms "Dual Career Family" and "Dual Career Couple" which have become increasingly significant lifestyles (Greenhaus, 1989; Sekaran, 1983, 1985, 1986). The concept of a dual-career family denotes a family structure in which the husband and wife simultaneously pursue active careers and family lives (Rapoport \& Rapoport, 1976). More recent definitions describe the dual-career couple as two people who each have a career and a shared relationship (Arnold, 1997). Although there are many positive benefits associated with dual career couples (Rapoport \& Rapoport, 1976; Bird \& Schnurman-Crook, 2005; Haddock \& Rattenborg, 2003; Parker \& Arthur, 2004), balancing the demands of work and home responsibilities contributes to increased stress and taxes the coping resources of the marital relationship (Parker \& Arthur, 2004). A couple's ability to manage these demands has important implications for their job, marital, and life satisfaction. At the same time, this rising tide of dual-career couples with young children and the changing 
of the traditional family structural configurations have resulted in substantial home and family responsibilities for both men and women (Allen, Herst, Bruck, \& Sutton, 2000). Thus, juggling responsibilities for work, housework, and child-care become strenuous resulting in work-family conflict (Razak, Yunus \& Nasurdin, 2011).

The present situation of Bangladesh (i.e. economic hardship combined with greater educational and employment opportunities for women, and particularly the growth of individualism and so on), have brought the discussion of WFC to the forefront. Since the present economic strain of Bangladesh has compelled many housewives to work outside of the home, the employment of women has upset the traditional balance of norms and values in the country (Khan, 2004). This results in a conflict between work and family. This can occur when one is either required to play two roles at the same time or plays different roles successively. Work responsibilities and family obligations compete for time and attention for most working couples. The more time individuals allocate to one area, the less they have to allocate to the other (Moen, Waismel-Manor \& Sweet, 2003). When individuals feel that too many demands of one domain are unmet, they experience WFC, which is consistent with a conflict approach to the relationship between work and family roles (Edwards \& Rothbard, 2000; Greenhaus \& Beutell, 1985; Lambert, 1990).

Rapoport and Rapoport $(1971,1976)$ have focused on the specific dynamics and tensions with dual career couples as they have to deal with decisions concerning work, career and family demands which lead to WFC. Specifically, WFC is defined as a form of inter-role conflict in which the role pressures from the work and family domains are mutually incompatible in some respect. That is, "participation in the work (family) role is made more difficult by virtue of participation in the family (work) role" (Greenhaus \& Beutell, 1985, p. 77). Frone, Russell and Cooper (1992) have identified two types of WFC; one is work-tofamily conflict, known as WFC, which happens when work is interfering with the family. 
Rahman, Tabassum, and Jahan

The other is family-to-work conflict (FWC), which happens when family life is interfering with work. Past researchers have found that high levels of both WFC and FWC are associated with decreased levels of job satisfaction (Higgins \& Duxbury, 1992; Byron, 2005; Kossek \& Ozeki, 1998; David \& Catherine, 2004; Parasuraman, Greenhaus \& Granrose, 1992), lower family satisfaction (Aryee, 1992; Carlson \& Kacmar, 2000; Byron, 2005; David \& Catherine, 2004; Kossek \& Ozeki, 1998; Parasuraman, Greenhaus \& Granrose, 1992; Parasuraman \& Simmers, 1991; Hammer, Cullen, Neal, Sinclair \& Shafiro, 2005), and life satisfaction (Byron, 2005; Duxbury \& Higgins, 1991) among dual career couples.

With the realized significance of WFC and FWC in terms of various types of satisfaction experienced by dual-career couples, it has become important to explore the nature of the relationship among these variables. As no prior study was found regarding WFC of dual-career couples in Bangladesh, the present study was aimed at understanding the influence of WFC and FWC on several outcomes, such as job satisfaction, family satisfaction and life satisfaction among dual career couples of Bangladesh.

\section{Theoretical Overview of WFC and FWC}

Most early research measures WFC, but does not identify the direction of conflict. It means the researchers did not identify whether the work roles were interfering in the family or the family roles were interfering in the work (Mesmer-Magnus \& Viswesvaran, 2005). Thus, the work domain that obstructs performance in the family domain (work-to-family conflict; WFC) and family demands that hinder performance in the work domain (family-towork conflict; FWC) are conceptually different (Netemeyer, Boles \& McMurrian, 1996). Kossek and Ozeki (1998) have suggested that FWC is more impacted by variables within the family domain, while WFC is more influenced by work-related variables. So, for a better understanding of the nature of WFC, it is important to consider the bi-directional conceptualization of WFC (Frone, Russell \& Cooper, 1992). In addition, many of the 
researchers questioned the fact of whether WFC and FWC were correlated with each other. As conflicts in one direction are likely to be coupled with expressions of conflict in the other direction, an overlap is expected between WFC and FWC (Frone, Russell \& Cooper, 1992). Though positive correlations were found between these two types of conflict (Gutek, Searle \& Klepa, 1991; Flye, Agars \& Kottke, 2003), researchers have suggested that WFC and FWC are distinct. Through a vast literature review, Mesmer-Magnus and Viswesvaran (2005) clarified the differential pattern of WFC and FWC. They mentioned in their research that: "WFC will correlate higher with job stressors and job satisfaction than FWC, but FWC will correlate higher (than WFC) with life satisfaction and non-job stressors (p. 217).”

\section{Work-family Conflict and Satisfaction}

Different researchers have demonstrated the negative consequences of WFC, which include low job performance (Frone, Yardley \& Markel, 1997; Kossek, Colquitt \& Noe, 2001) and low satisfaction levels with the job, family, and organization (Pleck, Staines \& Lang, 1980; Staines \& O'Connor, 1980; Greenhaus \& Kopelman, 1981; Jones \& Butler, 1980; Parasuraman, Towitz, Bedeian \& Mossholder, 1989; Aryee, 1992; Netemeyer et al., 1996; Lu, Huang \& Kao, 2005; Eby, Casper, Lockwood, Bordeaux \& Brinley, 2005). The conflict between work and family roles suggests that the structural, social, and psychological demands of work and family contribute to increasing levels of WFC by increasing demands of work and family (Frone, Russell \& Cooper, 1992). This stress leads to dissatisfaction with both work and family, and these two forms of distress cause general discontent and depression from such social and psychological demands as responsibility, a variety of tasks, workload, and psychological pressure. These are associated with a higher degree of WFC, with important consequences such as experience of work stress, work dissatisfaction, and poor functioning at work (Kinnunen \& Mauno, 1998; MacEwen \& Barling, 1988). Likewise, structural and social requirements of the family (number and age of children, care for 
Rahman, Tabassum, and Jahan

children, care for elders, marital status, quality of family member relationships) are associated with higher levels of FWC (Hill, Yang, Hawkins \& Ferris, 2004; Voydanoff, 2005) with important consequences such as family stress, dissatisfaction with family and fatigue, and inefficiency in marital and parenting functions (Frone, Yardley \& Markel, 1997; Kinnunen \& Mauno, 1998).

Different scholars have proven that high levels of both WFC and FWC have been associated with decreased levels of job satisfaction (Adams, King \& King, 1996; Duxbury \& Higgins, 1991; Thompson \& Blau, 1993; Wiley, 1987) and similar correlations have been reported for life satisfaction (Judge et al. 1994). Life satisfaction was conceptualized as being derived from satisfaction through having a good job and family life (Sekaran, 1983). Moreover, life satisfaction is increased through involvement in activities within the family domain and receipt of emotional support from family members (Judge et al. 1994). There is evidence that people with a high level of WFC tend to be less satisfied with their job and life (Allen, Herst, Bruck \& Sutton, 2000; Kossek \& Ozeki, 1998). Researchers have found that workers with high levels of WFC are at an increased physical and mental health risk. They have less satisfactory job performance, they are distracted at work, and more incidences of work withdrawal behaviors are reported (e.g., tardiness, absenteeism, and turnover). There is also reduced work engagement and decreased morale, which in turn may lead to lower satisfaction levels with job and life (Duxbury \& Higgins, 1991; Frone, Russell \& Cooper, 1992; Hammer, Bauer \& Grandey, 2003; Leiter \& Durup, 1996; O’Driscoll, Ilgen \& Hildreth, 1992).

The absence of enough time and energy for family activities due to the work demands may decrease the quality of family experiences (Aryee, Fields \& Luk, 1999; Frone, Russell \& Cooper, 1992). Thus, WFC can negatively relate to family satisfaction because these family related strain-based pressures include different factors such as parental conflict and marital 
discord (Byron, 2005). Several researchers have tested the relationship between WFC and family satisfaction and found a significant negative relation between these two variables (see Frone, Yardley \& Markel, 1997; Wayne, Musisca \& Fleeson, 2004). Based on the literature review, the current study was hypothesized in the following way.

Hypothesis 1: WFC negatively predicts job satisfaction among the dual career couples.

Hypothesis 2: FWC negatively predicts job satisfaction among the dual career couples.

Hypothesis 3: WFC negatively predicts family satisfaction among the dual career couples.

Hypothesis 4: FWC negatively predicts family satisfaction among the dual career couples.

Hypothesis 5: WFC negatively predicts life satisfaction among the dual career couples.

Hypothesis 6: FWC negatively predicts life satisfaction among the dual career couples.

Figure 1 provides a graphic depiction of the proposed theoretical model integrating the relationships among the variables based on the above hypotheses. Data were collected from the dual career couples and tests were conducted for measuring the theoretical model.

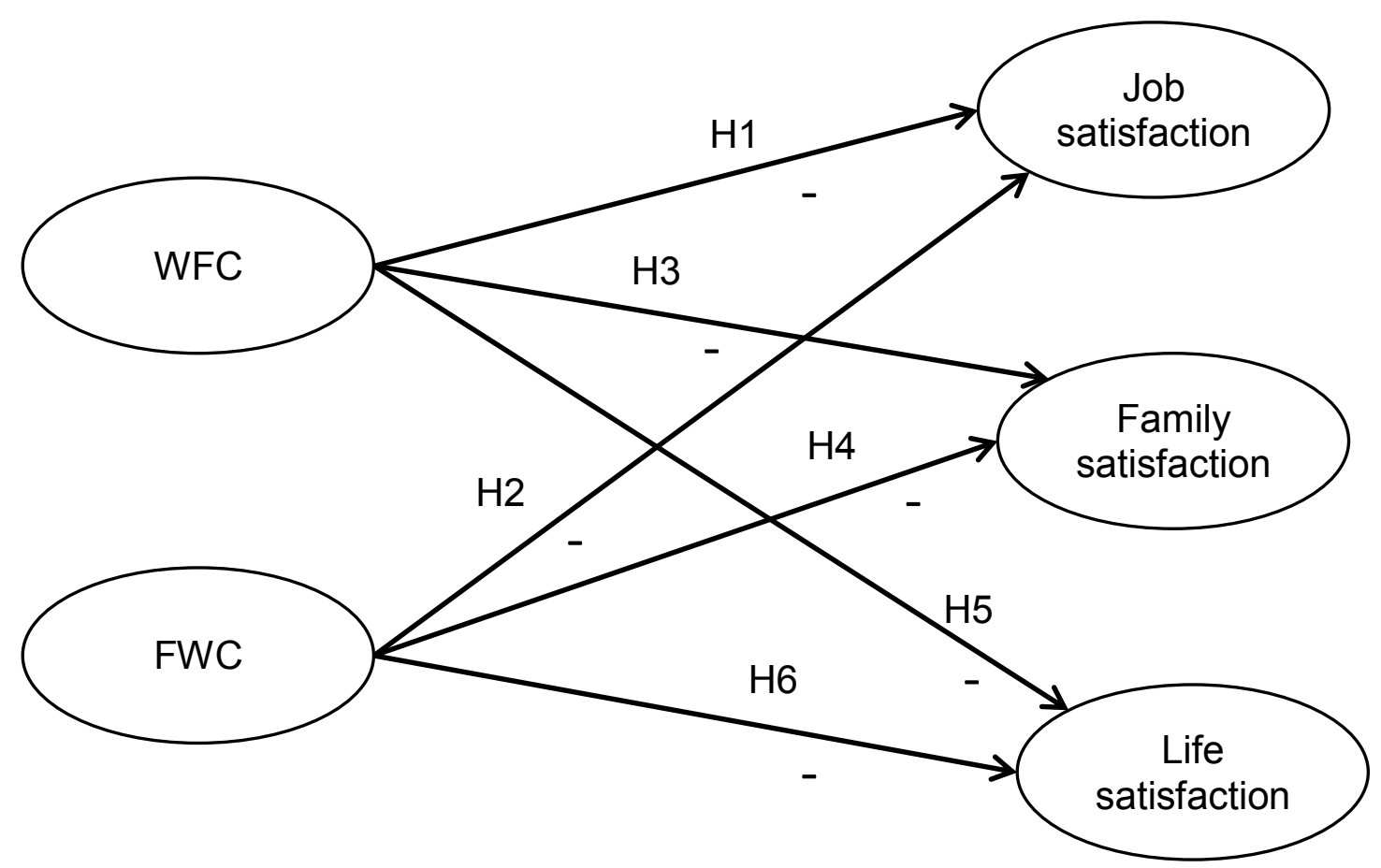

Figure 1: Proposed theoretical model for conflict and satisfaction for dual-career couples 
Rahman, Tabassum, and Jahan

\section{Methodology}

\section{Procedure}

The data was collected in Dhaka, the capital city of Bangladesh by means of a structured questionnaire. In total, 200 dual career couples were included as participants in the study on a voluntary basis. Among these, questionnaires of 180 couples were found to be usable for the research. Thus, a total number of 360 responses were considered for statistical analysis based on the corresponding husband-and-wife or marital relationship (180 male and 180 female participants).

\section{Participants}

Among the 360 respondents, $38.9 \%$ of the respondents fell in the age range of 21-30 years, $41.4 \%$ fell in the $31-40$ range, $16.9 \%$ fell in the $41-50$ range, and the rest, $2.8 \%$, had an age range of above 50 years. In terms of education level, $10.3 \%$ of the respondents were below the graduate level, $53.9 \%$ were graduates, and $30.3 \%$ were post-graduates. Among all of the respondents, $30.6 \%$ were public service holders and the rest, $69.4 \%$, were private service holders. All the participants were married and 79.4\% of them had children. Among those with children, $46.8 \%$ reported having one child, $41.9 \%$ had two children, and the rest, $11.1 \%$, had three children. Among the 180 couples, 55 couples lived in a joint family arrangement and the rest had formed nuclear families.

\section{Measures}

WFC and FWC were measured with the WFC and FWC scale adapted by Ali (2006). The scale included ten items such as: "The demands of my work interfere with my home family life" and "The demands of my family or spouse/partner interfere with work related activities" $(1=$ Never and $5=$ Always $)$. Both WFC and FWC were measured with five items.

Job satisfaction was assessed by using a self-constructed three-item scale.

Respondents were asked to indicate to what extent they "feel proud about their career", 
"happy with the growth rate of the career", and "are satisfied about the job/career". The answer format was a 5-point scale ranging from not at all (1) to a great deal (5). Similarly marital satisfaction was assessed by using a self-constructed three-item scale. Respondents were asked to indicate to what extent they "feel proud as a family-oriented person", "are satisfied about the marital life", and "their spouse is satisfied about marital life". Similar to the job satisfaction scale, the answer format was a 5-point scale ranging from not at all (1) to a great deal (5). Lastly, life satisfaction was also measured by using a self-constructed fiveitem scale. The scale included item statements such as "I am proud to be what I am and with what I have", "I am satisfied in my life though I am a member of a dual career family", etc. $(1$ = Strongly Disagree and $5=$ Strongly Agree $)$.

\section{Reliability and Validity of Data}

Validity is defined as the degree measures accurately represent what they are supposed to by Hair, Black, Babin, Anderson and Tatham (2007). According to Siddiqi (2010), validity is concerned with how well the concept is defined by the measure(s). There are three types of validity; content validity, predictive validity, and construct validity (Siddiqi, 2010). The current study focused on content validity. Duggirala, Rajendran and Anantharaman (2008) defined content validity as the assessment of the correspondence between the individual items and concept. Malhotra (2010) termed content validity as face validity. This study concentrated on content validity through the review of literature and adapted instruments which were used in previous research.

According to Hair et al. (2007), reliability differs from validity in that it relates not to what should be measured, but instead to how it is measured. Reliability is the extent to which a variable or set of variables is consistent in what it is intended to measure (Hair et al. 2007). The current study applied an internal consistency method because multiple items were used for all constructs. The Cronbach alpha with acceptable cut off point 0.70 demonstrates that all 
Rahman, Tabassum, and Jahan

attributes were internally consistent (Fujun, Hutchinson, Li \& Bai, 2007). The Cronbach alpha value for this study was 0.899 which meets the cut-off criteria point. Thus, all the attributes of the study were reliable.

\section{Statistical Tools for Data Analysis}

The responses were analyzed with the statistical software program SPSS. The study was based on the data collected to explore the relationship as well influence of WFC or FWC on job, family, and life satisfaction.

The researchers were able to rank the values, but the real distance between categories was unknown. Perception about conflict or enrichment was graded on scales from 'never' to 'always' or 'not at all' to 'great deal'. Survey respondents choose answers about the satisfaction on scales from 'strongly agree' to 'strongly disagree'. For computation of the scale median, the corresponding items have been considered as the calculation of the arithmetic mean is infeasible for this ordinal case. For assessing the basic insight of the female teachers, median and range have been computed to portray the centre and fluctuation of the dataset. Skewness along with the kurtosis has been measured to feature the size and shape of the distribution.

In the next step, Spearman Rank Correlation has been used for exploring the inherent linear relationship, but a dilemma was faced when exploring the inherent dependency. The ordinal categorical variables can be used as predictors, or factors, in many statistical procedures, such as linear regression. Then some difficult decisions should be made: Should the ordering of the values be forgotten and should these categorical variables be treated as if they are nominal? Should some sort of scale be substituted (for example, numbers 1 to 5) and the variables then pretend to be interval? To remove this quandary, the SPSS Ordinal Regression procedure, or PLUM (Polychromous Universal Model), has been used that is just an extension of the general linear model to ordinal categorical data. 


\section{Fitting an Ordinal Logit Model}

To fit a binary logistic regression model, we estimated a set of regression coefficients that predicted the probability of the outcome of interest. The version that shows what function of the probabilities results in a linear combination of parameters is -

$$
\ln \left(\frac{\operatorname{Pr}(\text { event })}{1-\operatorname{Pr}(\text { event })}\right)=\beta_{0}+\beta_{1} X_{1}+\beta_{2} X_{2}+\beta_{3} X_{3}+\ldots \ldots \ldots \ldots \ldots \ldots . . . .+\beta_{k} X_{k}
$$

The quantity to the left of the equal sign is called a logit. It is the log of the odds that an event occurs. This is what we get when we divide the probability that the event occurs by the probability that the event does not occur, since both probabilities have the same denominator and it cancels, leaving the number of events divided by the number of non-events. The coefficients in the logistic regression model tell us how much the logit changes based on the values of the predictor variables.

\section{Defining the Event}

In ordinal logistic regression, the event of interest is observing a particular score or less.

All of the odds are of the form:

$$
\theta_{j}=\frac{\operatorname{Pr}(\text { Score } \leq j)}{\operatorname{Pr}(\text { Score }>j)}
$$

We can also write the equation as -

$$
\theta_{j}=\frac{\operatorname{Pr}(\text { Score } \leq j)}{(1-\operatorname{Pr}(\text { Score } \leq j))}
$$

Since the probability of a score greater than $j$ is 1 - probability of a score less or equal to $j$.

\section{Ordinal Model}

The ordinal logistic model for a single independent variable is then-

$\ln \left(\theta_{j}\right)=\alpha_{j}-\beta X$ 
Rahman, Tabassum, and Jahan

Where, $j$ goes from 1 to the number of categories minus 1 .

In this case, larger coefficients indicate an association with larger scores. When we find a positive coefficient for a dichotomous factor, you know that higher scores are more likely for the first category. A negative coefficient tells you that lower scores are more likely. For a continuous variable, a positive coefficient tells you that as the values of the variable increase, the likelihood of larger scores increases. The ${ }^{\alpha_{j}}$ terms, called the threshold values that do not depend on the values of the independent variable for a particular case. They are like the intercept in a linear regression, except that each logit has its own.

\section{Results}

Inference on the Basic Features of the Study Variables

Table 1 represents some basic features of the data based on inter- conflict between the work and family life and achievement of satisfaction in these phases along with overall life.

Table 1: Descriptive statistics of the study variables

\begin{tabular}{|l|c|c|c|c|}
\hline & Median & Range & Skewness & Kurtosis \\
\hline WFC & 3.0000 & 4.00 & -0.499 & -0.458 \\
\hline FWC & 3.0000 & 4.00 & 0.052 & -0.785 \\
\hline Job Satisfaction & 4.0000 & 4.00 & -0.838 & 0.947 \\
\hline Family Satisfaction & 4.0000 & 4.00 & -0.946 & 0.630 \\
\hline Life Satisfaction & 4.0000 & 4.00 & -0.402 & 0.009 \\
\hline
\end{tabular}

The middle-most value can be found for achievement of satisfaction job, family and life expressing the 'agree' respondent for the cases. For the remaining cases, i.e. the cases of conflict, the median stays at exactly the nucleus of response expressing 'often' facing the conflict. The range of the dataset expresses the fact the responses are widely varied as the diversification shows a straight 4 in all cases. All the cases of satisfaction and conflict are expressing the most heterogeneous responses. The distribution of FWC is negatively skewed i.e. skewed to the left that is the only exceptional case than the others. The kurtosis was found 
negative in cases of conflict data implying the distribution is short-tailed. For the cases of achieving satisfaction, distribution is slim and long-tailed.

Table 2: Spearman Rank Correlation Analysis

\begin{tabular}{|l|c|c|c|c|c|}
\hline \multicolumn{1}{|c|}{ Variables } & WFC & FWC & $\begin{array}{c}\text { Job } \\
\text { Satisfaction }\end{array}$ & $\begin{array}{c}\text { Family } \\
\text { Satisfaction }\end{array}$ & $\begin{array}{c}\text { Life } \\
\text { Satisfaction }\end{array}$ \\
\hline \multirow{2}{*}{ WFC } & 1.000 & & & & \\
\hline \multirow{2}{*}{ FWC } & $0.365^{*}$ & 1.000 & & & \\
\cline { 2 - 6 } & $(0.000)$ & & & & \\
\hline \multirow{2}{*}{ Job Satisfaction } & $0.054^{*}$ & $-0.173^{*}$ & 1.000 & & \\
\cline { 2 - 6 } Family & $(0.009)$ & $\left(0.001^{)}\right.$ & & & \\
\hline \multirow{2}{*}{ Satisfaction } & $-0.049^{*}$ & $-0.244^{*}$ & $0.478^{*}$ & $(.000$ & \\
\cline { 2 - 7 } Life Satisfaction & $(0.033)$ & $(0.000)$ & $(0.000)$ & & \\
\cline { 2 - 7 } & $(0.013$ & -0.044 & $0.407^{*}$ & $0.485^{*}$ & \\
\hline
\end{tabular}

* Correlation is significant at the 0.05 level (2-tailed).

Table 2 represents the results of Spearman Rank Correlation analysis. The observed result shows, WFC is negatively correlated with family satisfaction and insignificant for life satisfaction. Interestingly, it is positively correlated with FWC and job satisfaction. FWC is significant and negative with job, family and life satisfaction. Job satisfaction has a positive linear association with that of family satisfaction and also overall life satisfaction. Again, family satisfaction has a significant positive linear relationship with that of the life satisfaction.

The following parts contain the models testing the hypothesis on prediction of satisfaction through conflict in home and away. Each table includes the ordinal regression models showing estimated coefficients for the model. The estimates labeled Threshold are the $\alpha j$ 's, the intercept equivalent terms. The estimates labeled Location are, actually, the matter of interest. They are the coefficients for the predictor variables. As is always the case with 
Rahman, Tabassum, and Jahan

categorical predictors in models with intercepts, the number of coefficients displayed is one less than the number of categories of the variable. The Wald statistic is the square of the ratio of the coefficient to its standard error. Based on the small observed significance level, the null hypothesis is rejected that expresses the statistic is zero.

According to Hypotheses1, WFC negatively predicts job satisfaction among the dual career couples. Now the ordinal regression model is going to be explored.

Table 3: Ordinal Regression Model for test the influence of WFC on Job Satisfaction

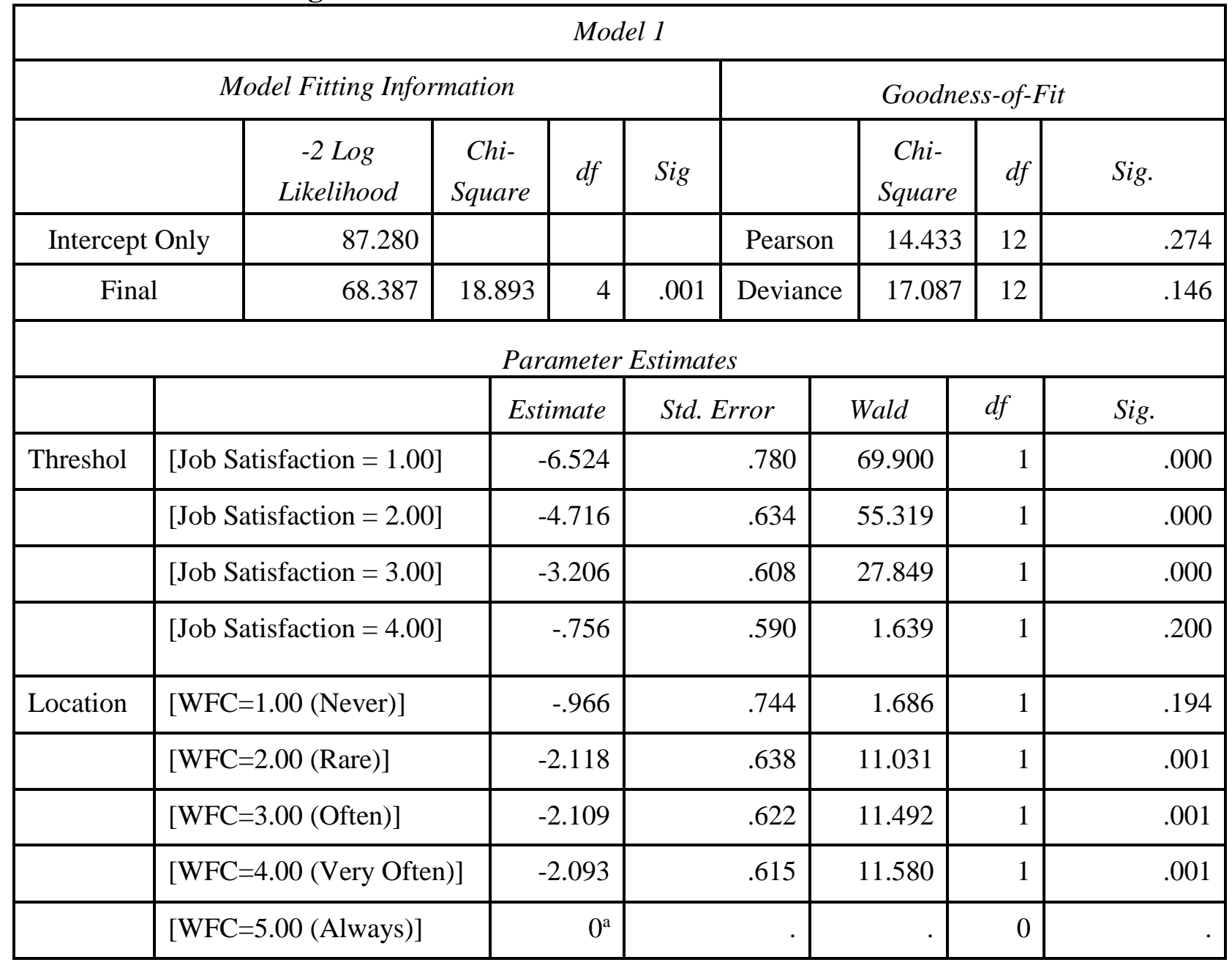

Link function: Logit.

a. This parameter is set to zero because it is redundant.

The coefficient of job satisfaction for those who face conflict in family life due to work is negative i.e. it is associated with poorer scores on the ranking of the couples. The odds ratio 
will be negative in each of the cases expressing that scores are lower to higher for satisfaction in job for those experiencing family conflict very often, often and rare. Thus, the expression says that dual career couple facing conflict very often, often, and rarely are less likely to assign higher rank in case of job satisfaction than those facing conflict very often. Thus higher job satisfaction has a higher risk of work-family conflict among them. So, Hypotheses 1 is rejected.

According to Hypotheses 2, FWC negatively predicts job satisfaction among the dual career couples. Now the ordinal regression model is going to be explored.

Table 4: Ordinal Regression Model for test the influence of FWC on Job Satisfaction

\begin{tabular}{|c|c|c|c|c|c|c|c|c|c|c|}
\hline \multicolumn{11}{|c|}{ Model 2} \\
\hline \multicolumn{6}{|c|}{ Model Fitting Information } & \multicolumn{5}{|c|}{ Goodness-of-Fit } \\
\hline & & $\begin{array}{c}-2 \log \\
\text { Likelihood }\end{array}$ & $\begin{array}{c}\text { Chi- } \\
\text { Square }\end{array}$ & $d f$ & Sig & & \multicolumn{2}{|c|}{$\begin{array}{c}\text { Chi- } \\
\text { Square }\end{array}$} & & Sig. \\
\hline \multicolumn{2}{|c|}{ Intercept Only } & 98.894 & & & & Pears & \multicolumn{2}{|c|}{26.783} & & .008 \\
\hline \multicolumn{2}{|c|}{ Final } & 80.230 & 18.664 & 4 & .001 & Devia & \multicolumn{2}{|c|}{28.796} & & .004 \\
\hline \multicolumn{11}{|c|}{ Parameter Estimates } \\
\hline & & & \multicolumn{2}{|c|}{ Estimate } & Std. $L$ & rror & Wald & \multicolumn{2}{|c|}{$d f$} & Sig. \\
\hline \multirow[t]{4}{*}{ Threshold } & \multicolumn{2}{|c|}{$[$ Job Satisfaction $=1.00]$} & & 1.710 & & .213 & 64.715 & \multicolumn{2}{|c|}{1} & .000 \\
\hline & \multicolumn{2}{|c|}{ [Job Satisfaction = 2.00] } & & .361 & & .177 & 4.167 & & 1 & .041 \\
\hline & \multicolumn{2}{|c|}{ [Job Satisfaction = 3.00] } & & 1.816 & & .202 & 81.220 & & 1 & .000 \\
\hline & \multicolumn{2}{|c|}{$[$ Job Satisfaction $=4.00]$} & & 5.094 & & .530 & 92.306 & & 1 & .000 \\
\hline \multirow[t]{5}{*}{ Location } & \multicolumn{2}{|c|}{$[\mathrm{FWC}=1.00$ (Never)] } & & .258 & & 1.301 & .039 & & 1 & .843 \\
\hline & \multicolumn{2}{|c|}{$[\mathrm{FWC}=2.00($ Rare $)]$} & & 1.306 & & .400 & 10.634 & & 1 & .001 \\
\hline & \multicolumn{2}{|c|}{$[\mathrm{FWC}=3.00($ Often $)]$} & & 1.108 & & .338 & 10.771 & & 1 & .001 \\
\hline & \multicolumn{2}{|c|}{$[\mathrm{FWC}=4.00($ Very Often $)]$} & & .639 & & .222 & 8.317 & & 1 & .004 \\
\hline & \multicolumn{2}{|c|}{$[\mathrm{FWC}=5.00$ (Always) $]$} & & $0^{\mathrm{a}}$ & & . & & & 0 & \\
\hline
\end{tabular}

The coefficient of Job satisfaction for those who very often, often and rarely face conflict in work life due to her family responsibilities is significantly positive i.e. it is associated with 
Rahman, Tabassum, and Jahan

higher scores on the ranking of the couples. In both cases, the odds ratio will be less than one revealing that scores are higher to lower for satisfaction in jobs for those experiencing work conflict rare, often, and very often than those experiencing always. Thus, Hypothesis 2 cannot be rejected and we can conclude family support is very important for achieving job satisfaction for any person.

According to Hypotheses 3, WFC negatively predicts family satisfaction among dual career couples. Now the ordinal regression model is going to be explored.

Table 5: Ordinal Regression Model for test the influence of WFC on Family Satisfaction

\begin{tabular}{|c|c|c|c|c|c|c|c|c|c|c|c|c|}
\hline \multicolumn{13}{|c|}{ Model 3} \\
\hline \multicolumn{7}{|c|}{ Model Fitting Information } & \multicolumn{6}{|c|}{ Goodness-of-Fit } \\
\hline & & $\begin{array}{c}-2 \log \\
\text { Likelihood }\end{array}$ & \multicolumn{2}{|c|}{$\begin{array}{c}\text { Chi- } \\
\text { Square }\end{array}$} & $d f$ & Sig & & \multicolumn{2}{|c|}{$\begin{array}{c}\text { Chi- } \\
\text { Square }\end{array}$} & & $d f$ & Sig. \\
\hline \multicolumn{2}{|c|}{ Intercept Only } & 82.360 & & & & & Pearson & \multicolumn{2}{|c|}{18.227} & & 2 & .109 \\
\hline \multicolumn{2}{|c|}{ Final } & 76.263 & \multicolumn{2}{|c|}{6.097} & 4 & .192 & Deviance & \multicolumn{2}{|c|}{21.547} & & 2 & .043 \\
\hline \multicolumn{13}{|c|}{ Parameter Estimates } \\
\hline & & & & \multicolumn{2}{|c|}{ Estimate } & Std. $L$ & rror & Wald & \multicolumn{2}{|c|}{$d f$} & & ig. \\
\hline \multirow[t]{4}{*}{ Threshold } & \multicolumn{3}{|c|}{$[$ Family Satisfaction $=1.00]$} & & 2.727 & & .273 & 99.573 & & 1 & & .000 \\
\hline & \multicolumn{3}{|c|}{$[$ Family Satisfaction $=2.00]$} & & -.907 & & .180 & 25.521 & & 1 & & .000 \\
\hline & \multicolumn{3}{|c|}{$[$ Family Satisfaction $=3.00]$} & & .448 & & .174 & 6.648 & & 1 & & .010 \\
\hline & \multicolumn{3}{|c|}{ [Family Satisfaction $=4.00]$} & & 3.559 & & .320 & 124.029 & & 1 & & .000 \\
\hline \multirow[t]{5}{*}{ Location } & \multicolumn{3}{|c|}{$[\mathrm{WFC}=1.00$ (Never) $]$} & & -.991 & & 1.292 & .589 & & 1 & & .443 \\
\hline & \multicolumn{3}{|c|}{$[\mathrm{WFC}=2.00($ Rare $)]$} & & -.045 & & .393 & .013 & & 1 & & .908 \\
\hline & \multicolumn{3}{|c|}{$[\mathrm{WFC}=3.00($ Often$)]$} & & .350 & & .336 & 1.088 & & 1 & & .297 \\
\hline & \multicolumn{3}{|c|}{$[\mathrm{WFC}=4.00$ (Very Often) $]$} & & .449 & & .219 & 4.217 & & 1 & & .040 \\
\hline & \multicolumn{3}{|c|}{$[\mathrm{WFC}=5.00$ (Always) $]$} & & $0^{\mathrm{a}}$ & & . & & & 0 & & \\
\hline
\end{tabular}

In case of Model 3, women are likely to give higher scores for achieving satisfaction in life facing very often Work-Family Conflict than those facing this problem always. The corresponding odds ratio is positive and confirms the fact that couples facing always WFC is 
enjoying less satisfaction in family life than those facing very often. Thus, Hypotheses 3 cannot be rejected.

According to Hypotheses 3, FWC negatively predicts family satisfaction among dual career couples. Now the ordinal regression model is going to be explored.

Table 6: Ordinal Regression Model for test the influence of FWC on Family Satisfaction

\begin{tabular}{|l|r|r|r|r|r|r|r|r|r|}
\hline \multicolumn{9}{|c|}{ Model 4 } \\
\hline \\
\hline
\end{tabular}

In case of Model 4, women are likely to give higher scores for achieving satisfaction in life facing rarely FWC than those facing always. The corresponding odds ratio is positive and confirms the fact that couple facing always WFC is enjoying much less satisfaction in the family life than those facing rarely. Thus, Hypotheses 4 cannot be rejected.

According to Hypotheses 5, FWC negatively predicts family satisfaction among dual career couples. Now the ordinal regression model is going to be explored. 
Rahman, Tabassum, and Jahan

Table 7: Ordinal Regression Model for test the influence of WFC on Life Satisfaction

\begin{tabular}{|c|c|c|c|c|c|c|c|c|c|c|c|}
\hline \multicolumn{12}{|c|}{ Model 5 : } \\
\hline \multicolumn{6}{|c|}{ Model Fitting Information } & \multicolumn{6}{|c|}{ Goodness-of-Fit } \\
\hline & & $\begin{array}{c}-2 \text { Log } \\
\text { Likelihood }\end{array}$ & $\begin{array}{c}\text { Chi- } \\
\text { Square }\end{array}$ & $d f$ & Sig & & \multicolumn{2}{|c|}{$\begin{array}{c}\text { Chi- } \\
\text { Square }\end{array}$} & & $d f$ & Sig. \\
\hline \multicolumn{2}{|c|}{ Intercept Only } & 73.277 & & & & Pears & \multicolumn{2}{|c|}{18.308} & & 8 & .019 \\
\hline \multicolumn{2}{|c|}{ Final } & 67.030 & 6.247 & 4 & .181 & Devia & \multicolumn{2}{|c|}{18.770} & & 8 & .016 \\
\hline \multicolumn{12}{|c|}{ Parameter Estimates } \\
\hline & & & \multicolumn{2}{|c|}{ Estimate } & \multicolumn{2}{|c|}{ Std. Error } & Wald & \multicolumn{2}{|c|}{$d f$} & & Sig. \\
\hline \multirow[t]{3}{*}{ Threshold } & \multicolumn{2}{|c|}{$[$ Life Satisfaction= 2.00] } & \multicolumn{2}{|c|}{-3.942} & & .603 & 42.727 & \multicolumn{2}{|c|}{1} & & .000 \\
\hline & \multicolumn{2}{|c|}{$[[$ Life Satisfaction $=3.00]$} & & 1.843 & & .572 & 10.390 & & 1 & & .001 \\
\hline & \multicolumn{2}{|c|}{$[[$ Life Satisfaction $=4.00]$} & & 1.147 & & .562 & 4.165 & & 1 & & .041 \\
\hline \multirow[t]{5}{*}{ Location } & \multicolumn{2}{|c|}{$[\mathrm{WFC}=1.00$ (Never)] } & & -.852 & & .731 & 1.360 & & 1 & & .244 \\
\hline & \multicolumn{2}{|c|}{$[\mathrm{WFC}=\mathbf{2 . 0 0}($ Rare $)]$} & & 1.319 & & .611 & 4.661 & & 1 & & .031 \\
\hline & \multicolumn{2}{|c|}{ [WFC=3.00 (Often)] } & & 1.461 & & .595 & 6.035 & & 1 & & .014 \\
\hline & \multicolumn{2}{|c|}{$[\mathrm{WFC}=4.00($ Very Often $)]$} & & 1.280 & & .586 & 4.760 & & 1 & & .029 \\
\hline & \multicolumn{2}{|c|}{$[\mathrm{WFC}=5.00$ (Always) $]$} & & $0^{\mathrm{a}}$ & & & & & 0 & & \\
\hline
\end{tabular}

In case of Model 5, the couples are likely to give lower scores for achieving life satisfaction facing less WFC that contradicts with our hypothesized view. The corresponding odds ratio is positive hugely in each category revealing the fact that the couple cannot avoid WFC for gaining more satisfaction in life. In other words, those who are facing less WFC cannot achieve enough life satisfaction.

In Table 7, the coefficients of life satisfaction are significantly negative for those facing WFC rarely, often, and very often than those facing always. Thus Hypotheses 5 is rejected.

According to Hypotheses 6, FWC negatively predicts family satisfaction among dual career couples. Now the ordinal regression model is going to be explored. 
Table 8: Ordinal Regression Model for test the influence of FWC on Life Satisfaction

\begin{tabular}{|c|c|r|r|r|r|r|r|r|r|}
\hline \multicolumn{8}{|c|}{ Model 6 : } \\
\hline \\
\hline
\end{tabular}

Link function: Logit.

a. This parameter is set to zero because it is redundant.

In the above model, no coefficients are found significant and thus Hypothesis 6 is rejected as there is no significant influence of FWC on life satisfaction.

\section{Discussion}

The purpose of the study was to investigate how WFC and FWC are related to job satisfaction, family satisfaction and life satisfaction, and to present a model that incorporated both WFC and FWC with these various types of satisfaction. As posited before, WFC is a bidirectional concept. Thus, the study tested hypotheses from both directions. The finding of the current study suggested a negative prediction of job satisfaction by WFC, but the study could not provide any evidence for FWC's negative prediction for job satisfaction. This finding is consistent with the previous research conducted on WFC and job satisfaction 
Rahman, Tabassum, and Jahan

(Allen, Herst, Bruck \& Sutton, 2000; Kossek \& Ozeki, 1998), where WFC was found to be strongly negatively related with job satisfaction. As both the family and work domains are interrelated, problems in one domain may create problems in another domain, thus creating dissatisfaction in terms of the job. This is obvious because in case of WFC, family responsibilities are constrained by work responsibilities and activities, which may hamper the job performance due to disturbances faced in the family domain. Thus, it may diminish the level of satisfaction one assumes from the job.

According to the current study results, WFC and FWC could not negatively predict family satisfaction of dual-career couples. This finding was not consistent with the past research conducted on various groups of working men and women (Byron, 2005; Kossek \& Ozeki, 1998; Perrone, Ægisdottir, Webb \& Blalock, 2006; Wayne, Musisca \& Fleeson, 2004), where both WFC and FWC was found to have adverse effect on family satisfaction. As work and family, these two domains are interrelated and success of one domain is dependent on the success of another domain, both WFC and FWC may have a negative impact on family satisfaction. But the findings of the present study are quite unusual in terms of previous literature. This may happen if the couples along with other family members are trying to cope up with the detrimental effect of WFC and FWC on family life.

In the current study, both WFC and FWC predicted life satisfaction negatively. This finding was consistent with the previous study findings (Netemeyer et al., 1996; Carlson \& Kacmar, 2000; Higgins, Duxbury \& Irving, 1992), where life satisfaction was negatively predicted by WFC and FWC. It is expected that WFC and FWC would lessen life satisfaction due to dissatisfaction in terms of both work and family.

\section{Practical Implications}

The study assesses various relationship patterns among WFC, FWC, job satisfaction, marital satisfaction, and life satisfaction. The nature of the relationship among these variables 
can be explored from the study in terms of dual career couples in Bangladesh. The organizations that employ dual career couples can have more elaborate ideas regarding the relationship of WFC, FWC and various types of satisfaction from this study. Therefore, it will help the employers to formulate work-family policies based on the findings of the current study. As WFC and FWC can significantly lower job satisfaction, marital satisfaction and life satisfaction, a collaborative effort of both the employers and employees is crucial for fostering a family-supportive work environment at the workplace. The current study can be a valuable source of empirical evidences for those practitioners who deal with dual career couples.

\section{Limitations and Future Research Direction}

There are limitations to this study that should be noted. First, the data was collected only from Dhaka city and as such, the findings cannot be generalized. Therefore, future research should be conducted on a larger scale by considering more dual career couples from all over Bangladesh to authenticate the findings of the study. Second, to determine the sample size and respondents, statistically accepted techniques should be utilized. It was not possible for the current researchers to adapt the statistically accepted techniques due to a lack of monetary and non-monetary resources. Third, the inferences drawn from this study are limited by self-reported data and cross-sectional characteristics of the data.

\section{Concluding Remarks}

The study was conducted to investigate the interrelation of WFC and FWC with job, family and life satisfaction among dual-career couples in Bangladesh. Results indicated that WFC faced by the dual-career couples can reduce job satisfaction among them. Though these working couples do not suffer from reduced family satisfaction due to WFC and FWC, life satisfaction can deteriorate due the bi-directional nature of WFC. As the organizational performance is dependent on its human resources, organizational competency can be affected 
Rahman, Tabassum, and Jahan

due to dissatisfied employees. To minimize these complexities, the employers of dual-career couples should devise their organizational policies in a family-friendly manner that will increase the employee performance as well as organizational performance. As the numbers of dual-career problems are increasing day by day, family counselors and dual-career couples together can figure out the coping strategies that will need to be employed in the search for the best breed of practice. Thus, it will be possible to ensure happy work-life, happy family and happy life for the dual-career couples. This is particularly important in the global business environment where businesses are continuously facing challenges for gaining sustainable competitive advantage. 


\section{References}

Adams, G.A., King, L.A., \& King, D.W. (1996). Relationships of job and family involvement, family social support, and work-family conflict with job and life satisfaction. Journal of Applied Psychology, 81(4), 411-420.

Allen, T.D., Herst, D., Bruck, C., \& Sutton, M. (2000). Consequences associated with workto-family conflict: A review and agenda for future research. Journal of Occupational and Health Psychology, 5, 278-308

Ali, E.A.H. (2006). The Relationship Between Work-Family Conflict (WFC) and FamilyWork Conflict (FWC) Towards Job Burnout: A Case at Sarawak Economic Development Corporation (SEDC). Dissertation of Masters degree, Universiti Utara Malaysia, Kedah, Malaysia.

Arnold, J. A. (1997). Managing careers into the 21st century. London: Paul Chapman

Aryee, S. (1992). Antecedents and outcomes of work-family conflict among married profes-sional women: Evidence from Singapore. Human Relations, 4, 813-837.

Aryee, S., Srinivas, E., \& Tan, H.H. (2005). Rhythms of life: antecedents and outcomes of work-family balance in employed parents. Journal of Applied Psychology, 90(1), 132146.

Beauregard, A.T. (2006). Are Organizations Shooting themselves in the foot? Work place contribution to family-to -work conflict. Equal Opportunities International, 25(5), 336-353.

Bird, G.W., \& Schnurman-Crook, A. (2005). Professional identity and coping behaviors in dual-career couples. Family Relations, 54, 145-160.

Byron, K. (2005). A meta-analytic review of work-family conflict and its antecedents, Journal of Vocational Behavior, 67, 169-198.

Carlson, D.S., \& Kacmar, M.K. (2000). Work-family conflict in the organization. Do life role values make a difference? Journal of Management, 26, 1031-1045.

Duggirala, M., Rajendran, C., \& Anantharaman, R.N. (2008). Provider-perceived Dimensions of total quality management in healthcare, Benchmarking, 15(6), 693-722.

Duxbury, L.E., \& Higgins, C.A. (1991). Gender differences in work-family conflict. Journal of Applied Psychology, 76(1), 60-74.

Eby, L.T., Casper, W.J., Lockwood, A., Bordeaux, C., \& Brinley, A. (2005). Work and family research in IO/OB: Content analysis and review of the literature (1980-2002), Journal of Vocational Behavior, 66, 124-197.

Edwards, J. R., \& Rothbard, N. P. (2000). Mechanisms linking work and family: Clarifying the relationship between work and family constructs. Academy of Management Review, 25(1), 178-199. 
Elloy, D.F., \& Smith, C. (2004). Antecedents of work-family conflict among dual-career couples: an Australian study. Cross Cultural Management: An International Journal, 11(4), 17-27.

Flye, L.P., Agars, M.D., \& Kottke, J.L. (2003). Organizational approaches to work-family conflict: Testing an integrative model. Paper presented at the meeting of the Society of Industrial Organizational Psychology, Orlando, FL.

Frone, M.R. (2003). Work-family balance, in J Campbell (Ed.), Handbook of occupational health psychology (pp. 143-162), Washington: American Psychological Association.

Frone, M.R., Russell, M., \& Cooper, M.L. (1992). Antecedents and outcomes of work-family conflict: Testing a model of the work-family interface. Journal of Applied Psychology, 77(1), 65-78.

Frone, M.R., Yardley, J.K., \& Markel, K.S. (1997). Developing and testing an integrative model of the work-family interface. Journal of Vocational Behavior, 50, 145-167.

Fujun, L., Hutchinson, J., Li, D., \& Bai, C. (2007). An empirical assessment and application of SERVQUAL in mainland China's mobile communications industry. The International Journal of Quality \& Reliability Management, 24(3), 244-260.

Greenhaus, J.H. (1989). Sources of work-family conflict among two-career couples. Journal of Vocational Behavior, 34(2), 133-53.

Greenhaus, J., \& Beutell, N. (1985). Sources of conflict between work and family roles. Academy of Management Review, 10, 76-88

Greenhaus, J., \& Kopelman, R. (1981). Conflict between work and nonwork roles: Implications for the career planning process. Human Resource Planning, 4, 1-10.

Gutek, B.A., Searle, S., \& Klepa, L. (1991). Rational versus gender role explanations for work family conflict. Journal of Applied Psychology, 76(4), 560-568.

Hair, J., Black, W., Babin, B., Anderson, R., \& Tatham, R. (2007). Multivariate Data Analysis, New Jersey: Pearson Education, Inc.

Haddock, S. A., \& Rattenborg, K. (2003). Benefits and challenges of dual-earning: Perspectives of successful couples. The American Journal of Family Therapy, 31, 325-344.

Hammer, L.B., Bauer, T.N., \& Grandey, A.A. (2003). Work-family conflict and work-related withdrawal behaviors. Journal of Business and Psychology, 17(3), 419-436.

Hammer, L.B., Cullen, J.C., Neal, M.B., Sinclair, R.R., \& Shafiro, M.V. (2005). The Longitudinal Effects of Work-Family Conflict and Positive Spillover on Depressive Symptoms Among Dual-Earner Couples. Journal of Occupational Health Psychology, 10(2), 138-154. 
Higgins, C.A., \& Duxbury, L.E. (1992). Work-family conflict: A comparison of dual-career and traditional-career men. Journal of Organizational Behavior, 13(4), 389-411.

Higgins, C.A., Duxbury, L.E., \& Irving, R.H. (1992). Work-family conflict in the dual-career family. Organizational Behavior and Human Decision Processes, 51, 51-75.

Hill, E.J., Yang, C., Hawkins, A.J., \& Ferris, M. (2004). A cross-cultural test of the workfamily interface in 48 countries. Journal of marriage and family, 66, 1300-1316.

Jones, A.P., \& Butler, M.C. (1980). A role transition approach to the stresses of organi-zationally-induced family disruption. Journal of Marriage and the Family, 43, 367-376.

Judge, T.A., Boudreau, J.W., \& Bretz, R.D. (1994). Job and life attitudes of male executives. Journal of Applied Psychology, 79, 767-782.

Khan, L. T. (2004, March 15). Marital instability in Dhaka, Bangladesh with special reference to dual-earner couples. Retrieved from http://www.lib.uchicago.edu/e/su/southasia/Lubna.html.

Kinnunen, U., \& Mauno, S. (1998). Antecedents and outcomes of work-family conflict among employed women and men in Finland. Human Relations, 51, 157-177.

Kossek, E.E., Colquitt, J.A., \& Noe, R.A. (2001). Care giving decisions, well-being, and performance: The effects of place and provider as a function of dependent type and work-family climates. Academy of Management Journal, 44, 29-44.

Kossek, E.E., \& Ozeki, C. (1998). Work-family conflict, policies, and the job-life satisfaction relationship: A review and directions for organizational behavior-human resources research. Journal of Applied Psychology, 83(2), 139-149.

Lambert, S. J. (1990). Processes linking work and family: A critical review and research agenda. Human Relations, 43(3), 239-257.

Leiter, M.P., \& Durup, M.J. (1996). Work, home, and in-between: A longitudinal study of spillover. Journal of Applied Behavioral Science, 32(1), 29-47.

Lu, L., Huang, M.T., \& Kao, S.F. (2005). The bi-directional conflict of work and family: Antecedents, consequences and moderators. Research in Applied Psychology, 27, $133-166$.

MacEwen, K.E., \& Barling, J. (1988), Interrole conflict, family support and marital adjustment of employed mothers: A short-term, longitudinal study. Journal of Organizational Behaviour, 9, 241-250.

Malhotra, N.K. (2010). Marketing Research: An Applied Orientation. $6^{\text {th }}$ ed. New Delhi: Pearson Education. 
Rahman, Tabassum, and Jahan

Mesmer-Magnus, J. R., \& Viswesvaran, C. (2005). Convergence between measures of workto-family and family-to-work conflict: A meta-analytic examination. Journal of Vocational Behavior, 67, 215-232.

Moen, P., Waismel-Manor, R., \& Sweet, S. (2003). It's About Time: Couples and Careers. . In P. Moen (Ed.), (pp. 133-152). Cornell University Press.

Netemeyer, R.G., Boles, J.S., \& McMurrian, R. (1996). Development and validation of work-family conflict and family-work conflict scales. Journal of Applied Psychology, $81(4), 400-410$.

O’Driscoll, M.P., Ilgen, D.R., \& Hildreth, K. (1992). Time devoted to job and off-job activities, interrole conflict, and affective experiences. Journal of Applied Psychology, 77(3), 272-279.

Parasuraman, S., Greenhaus, J.H., \& Granrose, C.S. (1992). Role stressors, social support, and well-being among two-career couples. Journal of Organizational Behavior, 13, 339-356.

Parasuraman, S., Greenhaus, J.R., Towitz, S.R., Bedeian, A.G., \& Mossholder, K.W. (1989). Work and family variables as mediators of the relationship between wives' employment and husbands' well-being. Academy of Management Journal, 32, 185201.

Parasuraman, S., \& Simmers, C.A. (2001). Type of employment, work-family conflict and well-being: a comparative study. Journal of Organizational Behavior, 22(5), 551-568.

Parker, P., \& Arthur, M. B. (2004). Giving voice to the dual-career couple. British Journal of Guidance \& Counselling, 32, 3-23.

Perrone, K.M., Ægisdottir, S., Webb, L.K., \& Blalock, R.H. (2006). Work-family interface: Commitment, conflict, coping, and satisfaction. Journal of Career Development, 32(3), 286-300.

Pleck, J., Staines, G., \& Lang, L. (1980). Conflict between work and family life. Monthly Labor Review, March, 29-32.

Rapoport, R., \& Rapoport, R.N. (1969). The Dual-Career Family: A Variant Pattern and Social Change. Human Relations, 22(1), 3-30.

Rapoport, R., \& Rapoport, R.N. (1971). Dual career families. London: Penguin.

Rapoport, R., \& Rapoport, R. (1976). Dual-career families re-examined. London: Martin Robertson and Co., Ltd.

Razak, A.Z.A.A., Yunus, N.K.Y., \& Nasrudin, M. (2011). The impact of work overload and job involvement on work-family conflict among Malaysian doctors. Labuan e-Journal of Muamalat and Society, 5, 1-10. 
Sekaran, U. (1983). Factors influencing the quality of life in dual-career families. Journal of Occupational Psychology, 56(2), 161-174.

Sekaran, U. (1985). The paths of mental health. Journal of Occupational Psychology, 58(2), 129-37.

Sekaran, U. (1986). Dual-Career Families - Contemporary Organizational and Counseling Issues, San Francisco: Jossey-Bass.

Sharafi, T., \& Shahrokh, Z.D. (2012). The relationship between family-to-work conflict of employee and co-workers' turnover Intention. Management Science Letters, 2, 1-10.

Siddiqi, K.O. (2010). Interrelations between service quality attributes, customer satisfaction and customer loyalty in the retail banking sector in Bangladesh. International Trade \& Academic Research Conference (ITARC), London.

Staines, G., \& O'Connor, P. (1980). Conflicts among work, leisure, and family roles. Monthly Labor Review, 103(3), 35-39.

van Daalen, G., Willemsen, T. M., \& Sanders, K. (2006). Reducing work-family conflict through different sources of social support. Journal of Vocational Behavior, 69, 462476.

Voydanoff, P. (2005). Toward a conceptualization of perceived work-family fit and balance: A demands and resources approach. Journal of Marriage and Family, 67, 822-836.

Wayne, J.H., Musisca, N., \& Fleeson, W. (2004). Considering the role of personality in the work-family experience: Relationships of the big five to work-family conflict and facilitation. Journal of Vocational Behavior, 64, 108-130. 